\title{
KEMAMPUAN BERINOVASI DOSEN PGSD FIP UNIVERSITAS NEGERI JAKARTA
}

\author{
Iva Sarifah
}

\begin{abstract}
Assuming that the leacture's ability to make innovation in the instructional activities can improve both the quality of instructional process and the quality of the student's learning achievement, this research was conducted to describe the the innovative activities performed by the lecturers in Primary School Teacher Education (PGSD) of School of Education, State University of Jakarta. The research conducted in the odd semester of the academic year 2007/2008, randomly selected 30 lectures of the Department as the respondents. From the data collected using questionair and analysed descriptively, the research concludes based on their teachng experience, the lectures with more than 15 years' teaching experience are more innovative than those with less experience.
\end{abstract}

Keywords: innovation, lecturer, teaching experience.

\section{PENDAHULUAN}

\section{Latar Belakang Masalah}

Jurusan Pendidikan Guru Sekolah Dasar (PGSD) merupakan salah satu jurusan yang berada pada Fakultas Ilmu Pendidikan Universitas Negeri Jakarta (FIP UNJ). Jurusan ini merupakan pengembangan dari Program Studi (Prodi) D2 PGSD yang diselenggarakan berdasarkan Surat Keputusan Menteri Pendidikan dan Kebudayaan No. 0854/O/ 1989 tanggal 30 Desember 1989, Tentang Pengadaan dan Pengayaan Guru Sekolah Dasar (Semiawan, 1994:1).

Program pendidikan yang dilaksanakan pada Prodi PGSD terdiri atas dua program, yakni program D2 dan S1. Program D2 merupakan program reguler dan nonreguler, sedangkan program S1 merupakan program reguler, nonreguler, dan alih program.

Harapan diselenggarakannya program ini tentunya untuk dapat menghasilkan lulusan yang dapat melaksanakan inovasi pembelajaran sehingga dapat meningkatkan mutu pendidikan, bukan hanya memperoleh ijazah saja. Untuk itu, berbagai upaya dilakukan agar dapat meningkatkan semua komponen yang terkait dengan penyelenggaraan program ini, baik faktor internal maupun faktor eksternal. Faktor tersebut di antaranya peningkatan terhadap efektivitas perkuliahan, peningkatan mutu dosen, peningkatan sarana dan prasarana, peningkatan sistem penilaian yang digunakan maupun berbagai upaya lain dalam rangka menumbuhkan atau meningkatkan motivasi belajar mahasiswa sehingga diharapkan terciptanya suasana perkuliahan yang optimal.
Peningkatan mutu dosen disinyalir merupakan salah satu upaya dalam mewujudkan tujuan penyelenggaraan program ini mengingat fungsi dosen sangat penting dalam melaksanakan perkuliahan. Untuk itu, sebagaimana tertera dalam UndangUndang RI Nomor 14 Tahun 2005 Tentang Guru dan Dosen, dinyatakan bahwa dalam melaksanakan tugas keprofesionalan, di antaranya dosen berkewajiban untuk: (1) melaksanakan pendidikan, penelitian, dan pengabdian kepada masyarakat; (2) merencanakan, melaksanakan proses pembelajaran, dan mengevaluasi hasil pembelajaran; serta (3) meningkatkan dan mengembangkan kualifikasi akademik serta kompetensi secara berkelanjutan sejalan dengan perkembangan ilmu pengetahuan, teknologi, dan seni (UU RI, 2005:43).

Untuk mampu melaksanakan tugas tersebut tentunya dosen harus memiliki keinovatifan. Hal ini mengingat dengan memiliki keinovatifan maka dosen akan terus berusaha untuk melakukan perubahan sesuai dengan tuntutan. Dosen yang memiliki keinovatifan tentunya akan mau menerima atau menghasilkan program-program dan ide-ide baru pada waktu tertentu. Dengan demikian, dosen Jurusan PGSD yang memiliki keinovatifan akan secara terus menerus berupaya untuk mengikuti perkembangan yang terjadi seiring dengan era globalisasi dan informasi. Upaya-upaya dalam mengikuti perkembangan ini tentunya akan memperkaya pengetahuan, wawasan bahkan keterampilan dosen yang pada akhirnya akan meningkatkan kompetensinya.

Dosen yang memiliki keinovatifan tentunya akan mampu melaksanakan perkuliahan dengan

Perspektif Ilmu Pendidikan - Vol. 17 Th. IX April 2008 
program-program atau ide-ide baru yang diperolehnya atau yang dikembangkannya. Hal ini tentunya akan berdampak pada peningkatan kualitas perkuliahan yang menjadi tanggung jawabnya yang pada akhirnya akan memberikan kontribusi yang sangat penting dalam meningkatkan kualitas penyelenggaraan Jurusan PGSD dalam upaya mewujudkan mutu pendidikan nasional.

Mengingat pentingnya keinovatifan dosen Jurusan PGSD maka peneliti merasa tertarik untuk melakukan penelitian. Harapan dari hasil penelitian ini adalah memberikan informasi dalam upaya meningkatkan kualitas penyelenggaraan Jurusan PGSD khususnya Jurusan PGSD FIP UNJ.

\section{Perumusan Masalah}

Berdasarkan latar belakang masalah di atas, rumusan masalah pada penelitian ini adalah bagaimanakah keinovatifan dosen Jurusan PGSD FIP UNJ apabila ditinjau dari pengalaman membelajarkan sampai dan lebih dari 15 tahun?

\section{Manfaat Penelitian}

Penelitian ini diharapkan dapat memberikan manfaat bagi:

1. FIP UNJ sebagai masukan dalam pelaksanaan kontrol untuk mewujudkan visi, misi, dan tujuan fakultas;

2. Jurusan PGSD FIP UNJ sebagai masukan dalam meningkatkan penyelenggaraan jurusan sehingga visi, misi, dan tujuan penyelenggaraan jurusan dapat tercapai secara optimal;

3. dosen Jurusan PGSD FIP UNJ sebagai masukan dalam meningkatkan kompetensinya; dan

4. peneliti selanjutnya, sebagai sumbangan pemikiran dalam melakukan penelitian terkait dengan efektivitas penyelenggaraan Jurusan PGSD.

\section{KAJIAN TEORETIS}

\section{Hakikat Keinovatifan}

Perubahan merupakan bagian dari suatu inovasi. Kata "inovasi" diadopsi dari bahasa Latin "innovare" yang berarti membuat sesuatu yang baru (Tidd: 94, 24). Senada dengan itu Seymour (1988:2) memakai kata kerja to innovate, yaitu proses membuat cara-cara baru dalam melakukan sesuatu, proses pembuatan tersebut berawal dari kreativitas individu dalam memperhatikan sampai kepada implementasi atau penerimaan.

Menurut Drucker (1985:134-139), secara umum ciri inovasi adalah (1) susunan pembaruan dimulai dengan menganalisis peluang; (2) pembaruan adalah perpaduan antara konsepsi dan persepsi; (3) pembaruan itu efektif, simpel, dan dipusatkan pada sesuatu; (4) pembaruan yang efektif dimulai dari yang kecil; dan (5) keberhasilan tujuan pembaruan terletak pada kepemimpinan. Pendapat ini mengungkapkan bahwa inovasi merupakan suatu pembaharuan yang dimulai dengan menganalisis peluang merupakan perpaduan antara konsepsi dan persepsi, serta ditentukan oleh kepemimpinan.

Adapun keinovatifan adalah suatu tingkat kecepatan relatif individu atau unit adopsi dalam mengadopsi suatu inovasi jika dibandingkan dengan individu atau sistem lainnya. Keinovatifan menunjukkan perubahan perilaku sesuai dengan tujuan difusi inovasi, dengan kata lain perubahan tidak hanya sekedar bersifat kognitif atau perubahan sikap. Keinovatifan adalah bentuk dasar yang membatasi perilaku dalam proses inovasi yang dikategorikan ke dalam inovator, pengadopsi awal (early adopter), mayoritas awal (early mayority), mayoritas akhir, (late mayority), dan kolot (laggard) (Roger, 1995:22).

Menurut Scheirer (1981:25) keinovatifan adalah penerimaan terhadap sejumlah program-program dan ide-ide baru pada waktu tertentu. Penerimaan terhadap perubahan atau inovasi mencakup pemahaman individu tentang perubahan berupa pengetahuan dan informasi yang diterima tentang perubahan, komitmennya terhadap perubahan dan keterlibatannya dalam pelaksanaan perubahan. Sehubungan dengan penerimaan tersebut, Hender (1981:16) menegaskan bahwa keinovatifan pelaksana pendidikan adalah adanya perubahan sikap dan tidak hanya sekedar menerima inovasi apa adanya dari luar.

Selanjutnya keinovatifan adalah suatu bentuk keinginan kuat dalam merubah cara melakukan sesuatu. Perubahan tersebut terlihat dalam memikir ulang cara-cara berperilaku dan kemungkinan perubahan pola-pola kerja dalam bentuk rancangan untuk menghadapi masa yang akan datang dan permasalahan yang mungkin muncul ( $\mathrm{O}^{\prime}$ Conner, 1993:16).

Berdasarkan uraian tersebut maka yang dimaksud keinovatifan adalah kadar atau derajat keinginan yang ditunjukkan dalam bentuk perilaku dalam menerima gagasan baru, program baru maupun produk baru. Bentuk dasar yang membatasi perilaku dalam proses inovasi yang dikategorikan ke dalam inovator, pengadopsi awal (early adopter), mayoritas awal (early mayority), mayoritas akhir, (late mayority), dan kolot (laggard). 


\section{Keinovatifan Dosen Jurusan PGSD FIP UNJ}

Sebagaimana telah dikemukakan bahwa keinovatifan adalah kadar atau derajat keinginan yang ditunjukkan dalam bentuk perilaku dalam menerima gagasan baru, program baru maupun produk baru. Bentuk dasar yang membatasi perilaku dalam proses inovasi yang dikategorikan ke dalam inovator, pengadopsi awal (early adopter), mayoritas awal (early mayority), mayoritas akhir, (late mayority), dan kolot (laggard). Adapun keinovatifan dosen Jurusan PGSD FIP UNJ adalah gambaran derajat keinginan yang ditunjukkan dalam perilaku seorang dosen Jurusan PGSD FIP UNJ dalam melakukan pembaruan atau menyerap berbagai bentuk pembaruan sejalan dengan tugas dan fungsinya sebagai tenaga edukatif.

Berdasarkan uraian di atas yang dimaksud dengan keinovatifan dosen Jurusan PGSD FIP UNJ dalam penelitian ini adalah kadar atau derajat keinginan yang ditunjukkan dalam bentuk perilaku dosen Jurusan PGSD FIP UNJ dalam menerima ide atau gagasan baru, program baru maupun produk baru dalam bidang pendidikan. Bentuk dasar yang membatasi perilaku dalam proses inovasi yang dikategorikan ke dalam inovator, pengadopsi awal (early adopter), mayoritas awal (early mayority), mayoritas akhir, (late mayority), dan kolot (Laggard).

\section{METODOLOGI PENELITIAN}

\section{Tujuan Penelitian}

Tujuan penelitian ini adalah untuk mengetahui bagaimana keinovatifan dosen Jurusan PGSD FIP UNJ ditinjau dari pengalaman mengajar sampai dan lebih dari 15 tahun.

\section{Tempat dan Waktu Penelitian}

Penelitian dilakukan di Jurusan PGSD FIP UNJ, Jl. Setiabudi I No. 1 Jakarta Selatan. Penelitian dilaksanakan pada semester ganjil tahun akademik 2007/2008.

\section{Metode Penelitian}

Sesuai dengan tujuan penelitian yang dirumuskan maka metode yang digunakan dalam penelitian ini adalah metode deskriptif dengan teknik survei. Hal ini mengingat, peneliti pada penelitian ini hanya mendeskripsikan tentang keinovatifan dosen Jurusan PGSD FIP UNJ bukan untuk menguji hipotesis.

\section{Populasi dan Sampel}

Populasi dalam penelitian ini adalah seluruh dosen Jurusan PGSD FIP UNJ. Adapun yang menjadi sampel dalam penelitian ini adalah dosen tetap Jurusan PGSD FIP UNJ. Sampel penelitian dipilih dengan menggunakan teknik pengambilan sampel acak sederhana (simple random sampling). Adapun jumlah sampel penelitian adalah 30 orang.

\section{Teknik Pengumpulan Data}

Data dalam penelitian ini terkait dengan keinovatifan dosen Jurusan PGSD FIP UNJ. Data ini dikumpulkan dengan menggunakan teknik nontes, yakni berupa angket menggunakan skala Likert. Instrumen yang digunakan dalam menjaring data penelitian ini disusun oleh peneliti dengan mengacu pada teori tentang keinovatifan sebagaimana telah dipaparkan pada Bab II dan dikonsultasikan kepada pakar pendidikan.

Adapun kisi-kisi instrumen keinovatifan dosen Jurusan PGSD FIP UNJ yang digunakan dapat dilihat pada Tabel berikut.

Tabel 1. Kisi-kisi Instrumen Keinovatifan Dosen Jurusan PGSD FIP UNJ

\begin{tabular}{|c|c|c|c|c|}
\hline \multirow{2}{*}{ Aspek } & \multirow{2}{*}{ Indikator } & \multicolumn{2}{|c|}{ Nomor Butir } & \multirow{2}{*}{ Jml } \\
\hline & & Positif & Negatif & \\
\hline \multirow{3}{*}{$\begin{array}{l}\text { Ide/Gagasan } \\
\text { Baru dalam } \\
\text { pendidikan }\end{array}$} & $\begin{array}{l}\text { 1. Menerima ide } \\
\text { baru }\end{array}$ & 15,17 & 18,5 & \multirow[b]{3}{*}{14} \\
\hline & $\begin{array}{l}\text { 2. Mencoba ide } \\
\text { baru }\end{array}$ & $9,27,32$ & $2,8,16$ & \\
\hline & $\begin{array}{l}\text { 3. Menerapkan ide } \\
\text { baru }\end{array}$ & 30,35 & 28,31 & \\
\hline \multirow{3}{*}{$\begin{array}{l}\text { Program Baru } \\
\text { dalam } \\
\text { pendidikan }\end{array}$} & $\begin{array}{l}\text { 1. Menerima } \\
\text { program baru }\end{array}$ & 25,26 & 23,24 & \multirow[b]{3}{*}{13} \\
\hline & $\begin{array}{l}\text { 2. Mencoba } \\
\text { program baru }\end{array}$ & 6,20 & 3,12 & \\
\hline & $\begin{array}{l}\text { 3. } \text { Menerapkan } \\
\text { program baru }\end{array}$ & $4,10,29$ & 37,40 & \\
\hline
\end{tabular}




\begin{tabular}{|c|c|c|c|c|c|}
\hline \multirow{3}{*}{$\begin{array}{l}\text { Produk Baru } \\
\text { dalam } \\
\text { pendidikan }\end{array}$} & & $\begin{array}{l}\text { Menerima } \\
\text { produk baru }\end{array}$ & $1,11,33$ & 14,41 & \multirow[b]{3}{*}{14} \\
\hline & 2. & $\begin{array}{l}\text { Mencoba } \\
\text { produk baru }\end{array}$ & 36,38 & 21,39 & \\
\hline & & $\begin{array}{l}\text { Menerapkan } \\
\text { produk baru }\end{array}$ & $7,13,19$ & 22,34 & \\
\hline \multicolumn{3}{|c|}{ Jumlah } & 22 & 19 & 41 \\
\hline
\end{tabular}

\section{Teknik Analisis Data}

Untuk mendapatkan data tentang keinovatifan dosen Jurusan PGSD FIP UNJ maka teknik yang digunakan dalam menganalisis data penelitian ini menggunakan teknik analisis deskriptif. Artinya, analisis dilakukan dengan mendeskripsikan rerata keinovatifan dosen Jurusan PGSD FIP UNJ. Analisis dilakukan terhadap kedua kelompok responden, yakni responden yang memiliki pengalaman membelajarkan sampai 15 tahun dan lebih dari 15 tahun.

Untuk memperoleh gambaran tentang keinovatifan, keseluruhan analisis dilakukan dengan memperhatikan kelompok pengalaman membelajarkan, yakni keinovatifan tinggi dan rendah. Pengelompokkan keinovatifan dilakukan dengan menggunakan teori Flanagan (Semiawan, 1986:72), yakni menentukan sebanyak $27 \%$ dari data yang dianalisis. Dengan demikian, kelompok data yang memiliki keinovatifan tinggi sebanyak $27 \%$ kelompok atas dari data yang sudah diurutkan sedangkan kelompok data yang memiliki keinovatifan rendah sebanyak $27 \%$ kelompok bawah dari data yang sudah diurutkan.

\section{HASIL PENELITIAN}

\section{Deskripsi Data}

Sebagaimana telah dikemukakan bahwa penelitian ini bertujuan untuk mengetahui bagaimana keinovatifan dosen Jurusan PGSD FIP UNJ ditinjau dari pengalaman membelajarkan. Untuk itu maka hasil penelitian ini dikelompokkan dalam dua bagian, yakni keinovatifan dosen Jurusan PGSD FIP UNJ yang berpengalaman membelajarkan sampai 15 tahun dan yang berpengalaman membelajarkan lebih dari 15 tahun. Selain itu, data dalam penelitian inipun dikelompokkan dalam tiga aspek keinovatifan, yakni aspek ide atau gagasan baru dalam perkuliahan, aspek program baru dalam perkuliahan, dan aspek produk baru dalam perkuliahan. Dari keseluruhan kelompok data dianalisis berdasarkan keinovatifan rendah dan tinggi.

1. Keinovatifan dosen Jurusan PGSD FIP UNJ yang berpengalaman membelajarkan sampai 15 Tahun
Data penelitian diperoleh dari 13 orang responden, yakni dosen Jurusan PGSD FIP UNJ yang berpengalaman membelajarkan sampai 15 tahun, dengan mengukur variabel keinovatifan. Berdasarkan hasil deskripsi data dengan menggunakan program excel 2000 maka diperoleh skor terendah 131 dan skor tertinggi 165 sehingga rentangannya 34 dari rentang teoretis 0 sampai 205; skor rerata $=148,2$; median $=$ $147 ;$ modus $=149 ;$ dan standar deviasi $=8,719$.

Apabila ditinjau dari aspek ide atau gagasan baru dalam pendidikan, diperoleh skor terendah 44 dan skor tertinggi 61 sehingga rentangannya 17 dari rentang teoretis 0 sampai 70 ; skor rerata $=51,38$; median $=51$; modus $=55 ;$ dan standar deviasi $=4,482$.

Apabila ditinjau dari aspek program baru dalam pendidikan, diperoleh skor terendah 38 dan skor tertinggi 53 sehingga rentangannya 15 dari rentang teoretis 0 sampai 65 ; skor rerata $=44$; median $=43$; modus $=46$; dan standar deviasi $=4,143$.

Apabila ditinjau dari aspek produk baru dalam pendidikan, diperoleh skor terendah 40 dan skor tertinggi 55 sehingga rentangannya 15 dari rentang teoretis 0 sampai 65 ; skor rerata $=49,5$; median $=49$; modus $=48$; dan standar deviasi $=3,76$.

2. Keinovatifan dosen jurusan PGSD FIP UNJ yang berpengalaman membelajarkan lebih dari 15 Tahun

Data penelitian diperoleh dari 22 orang responden, yakni dosen Jurusan PGSD FIP UNJ yang berpengalaman membelajarkan lebih dari 15 tahun, dengan mengukur variabel keinovatifan. Berdasarkan hasil deskripsi data dengan menggunakan program excel 2000 maka diperoleh skor terendah 100 dan skor tertinggi 148 , sehingga rentangannya 48 dari rentang teoretis 0 sampai 205 ; skor rerata $=127,9$; median $=$ 129,5; modus = 129; dan standar deviasi $=13,12$.

Apabila ditinjau dari aspek ide atau gagasan baru dalam pendidikan, diperoleh skor terendah 25 dan skor tertinggi 54 sehingga rentangannya 29 dari rentang teoretis 0 sampai 175 ; skor rerata $=45,05$; median $=46,5$; modus $=47 ;$ dan standar deviasi $=7,054$.

Apabila ditinjau dari aspek program baru dalam pendidikan, diperoleh skor terendah 27 dan skor tertinggi 49 sehingga rentangannya 22 dari rentang teoretis 0 sampai 200; skor rerata $=38$; median $=38$; modus $=41 ;$ dan standar deviasi $=5,09$. 
Apabila ditinjau dari aspek produk baru dalam pendidikan, diperoleh skor terendah 27 dan skor tertinggi 51 sehingga rentangannya 24 dari rentang teoretis 0 sampai 205; skor rerata $=41,59$; median $=$ 42,5; modus $=44 ;$ dan standar deviasi $=6,397$.

\section{Analisis Data}

Sebagaimana yang telah dikemukakan bahwa analisis data dilakukan terhadap kelompok dosen yang memiliki pengalaman membelajarkan sampai dan lebih dari 15 tahun. Analisis dilakukan dengan mengelompokkan data dengan menggunakan rumus Planagan sehingga dari kedua kelompok data tersebut diperoleh kelompok dosen yang memiliki keinovatifan tinggi dan rendah. Berdasarkan pengelompokkan keinovatifan, diperoleh pula rerata keinovatifan. Berikut hasil analisis data yang dilakukan terhadap masing-masing kelompok dosen.

1. Keinovatifan kelompok dosen yang memiliki pengalaman membelajarkan sampai 15 Tahun

Keinovatifan dosen yang memiliki pengalaman membelajarkan sampai 15 tahun dianalisis dengan menggunakan rumus Planagan. Hasil analisis diperoleh dosen yang memiliki keinovatifan tinggi dan rendah masing-masing sebanyak empat orang. Kelompok dosen yang memiliki keinovatifan rendah memperoleh skor 131, 142, 143, dan 144. Sementara kelompok dosen yang memiliki keinovatifan tinggi memperoleh skor 152, 153, 162, dan 165. Adapun rerata kelompok dosen yang memiliki keinovatifan rendah adalah 140. Sementara rerata kelompok dosen yang memiliki keinovatifan tinggi adalah 158 .

Apabila ditinjau dari aspek ide atau gagasan baru dalam pendidikan maka untuk keinovatifan dosen yang memiliki pengalaman membelajarkan sampai 15 tahun, diperoleh dosen yang memiliki keinovatifan tinggi dan rendah masing-masing sebanyak tiga orang. Kelompok dosen yang memiliki keinovatifan rendah memperoleh skor 44, 46, 48, dan 49. Sementara kelompok dosen yang memiliki keinovatifan tinggi memperoleh skor 54, 55, 55, dan 61. Adapun rerata kelompok dosen yang memiliki keinovatifan rendah adalah 46,75 . Sementara rerata kelompok dosen yang memiliki keinovatifan tinggi adalah 56,25.

Apabila ditinjau dari aspek program baru dalam pendidikan maka untuk keinovatifan dosen yang memiliki pengalaman membelajarkan sampai 15 tahun, diperoleh dosen yang memiliki keinovatifan tinggi dan rendah masing-masing sebanyak empat orang. Kelompok dosen yang memiliki keinovatifan rendah memperoleh skor 38, 39, 41, dan 42. Sementara kelompok dosen yang memiliki keinovatifan tinggi memperoleh skor 46, 46, 50, dan 53. Adapun rerata kelompok dosen yang memiliki keinovatifan rendah adalah 40. Sementara rerata kelompok dosen yang memiliki keinovatifan tinggi adalah 48,75.

Apabila ditinjau dari aspek produk baru dalam pendidikan maka keinovatifan dosen yang memiliki pengalaman membelajarkan sampai 15 tahun, diperoleh dosen yang memiliki keinovatifan tinggi dan rendah masing-masing sebanyak empat orang. Kelompok dosen yang memiliki keinovatifan rendah memperoleh skor 40,46, 47, dan 48. Sementara kelompok dosen yang memiliki keinovatifan tinggi memperoleh skor 51, 52, 53, dan 55. Adapun rerata kelompok dosen yang memiliki keinovatifan rendah adalah 45,25 . Sementara rerata kelompok dosen yang memiliki keinovatifan tinggi adalah 52,75.

2. Keinovatifan kelompok dosen yangmemiliki pengalaman membelajarkan lebih dari 15 Tahun

Keinovatifan dosen yang memiliki pengalaman membelajarkan lebih dari 15 tahun dianalisis dengan menggunakan rumus Planagan. Hasil analisis diperoleh dosen yang memiliki keinovatifan tinggi dan rendah masing-masing sebanyak enam orang. Kelompok dosen yang memiliki keinovatifan rendah memperoleh skor 100, 104, 107, 113, 114, dan 123. Sementara kelompok dosen yang memiliki keinovatifan tinggi memperoleh skor 138, 139, 139, 143, 143, dan 148. Adapun rerata kelompok dosen yang memiliki keinovatifan rendah adalah 110,167. Sementara rerata kelompok dosen yang memiliki keinovatifan tinggi adalah 141,667.

Apabila ditinjau dari aspek ide atau gagasan baru dalam pendidikan maka keinovatifan dosen yang memiliki pengalaman membelajarkan lebih dari 15 tahun, diperoleh dosen yang memiliki keinovatifan tinggi dan rendah masing-masing sebanyak enam orang. Kelompok dosen yang memiliki keinovatifan rendah memperoleh skor 25, 31, 38, 41, 42, dan 42. Sementara kelompok dosen yang memiliki keinovatifan tinggi memperoleh skor 49, 51, 51, 53, 54, dan 54 . Adapun rerata kelompok dosen yang memiliki keinovatifan rendah adalah 36,5 . Sementara rerata kelompok dosen yang memiliki keinovatifan tinggi adalah 52 .

Apabila ditinjau dari aspek program baru dalam pendidikan maka keinovatifan dosen yang memiliki pengalaman membelajarkan lebih dari 15 tahun, diperoleh dosen yang memiliki keinovatifan tinggi dan rendah masing-masing sebanyak enam orang. Kelompok dosen yang memiliki keinovatifan rendah memperoleh skor 27, 32, 32, 32, 33, dan 35. Sementara 
kelompok dosen yang memiliki keinovatifan tinggi memperoleh skor 41,41, 43, 44, 45, dan 49. Adapun rerata kelompok dosen yang memiliki keinovatifan rendah adalah 31,833 . Sementara rerata kelompok dosen yang memiliki keinovatifan tinggi adalah 43,833.

Apabila ditinjau dari aspek produk baru dalam pendidikan maka keinovatifan dosen yang memiliki pengalaman membelajarkan lebih dari 15 tahun, diperoleh dosen yang memiliki keinovatifan tinggi dan rendah masing-masing sebanyak enam orang. Kelompok dosen yang memiliki keinovatifan rendah memperoleh skor 27, 33, 33, 34, 36, dan 37. Sementara kelompok dosen yang memiliki keinovatifan tinggi memperoleh skor 48, 48, 48, 49, 50, dan 51. Adapun rerata kelompok dosen yang memiliki keinovatifan rendah adalah 33,333. Sementara rerata kelompok dosen yang memiliki keinovatifan tinggi adalah 49 .

\section{Pembahasan Hasil Penelitian}

Berdasarkan hasil analisis diperoleh rerata keinovatifan dosen Jurusan PGSD FIP UNJ yang memiliki pengalaman membelajarkan sampai 15 tahun sebesar 148,2. Sementara rerata keinovatifan dosen yang memiliki pengalaman membelajarkan lebih dari 15 tahun sebesar 127,9. Apabila ditinjau dari aspek ide atau gagasan baru dalam pendidikan, diperoleh rerata keinovatifan dosen Jurusan PGSD FIP UNJ yang memiliki pengalaman membelajarkan sampai 15 tahun sebesar 51,38. Sementara rerata keinovatifan dosen yang memiliki pengalaman membelajarkan lebih dari 15 tahun sebesar 45,05.

Apabila ditinjau dari aspek program baru dalam pendidikan, diperoleh rerata keinovatifan dosen Jurusan PGSD FIP UNJ yang memiliki pengalaman membelajarkan sampai 15 tahun sebesar 44 . Sementara rerata keinovatifan dosen yang memiliki pengalaman membelajarkan lebih dari 15 tahun sebesar 38. Apabila ditinjau dari aspek produk baru dalam pendidikan, diperoleh rerata keinovatifan dosen Jurusan PGSD FIP UNJ yang memiliki pengalaman membelajarkan sampai 15 tahun sebesar 49,5. Sementara rerata keinovatifan dosen yang memiliki pengalaman membelajarkan lebih dari 15 tahun sebesar 41,59.

Adapun rerata kelompok dosen Jurusan PGSD FIP UNJ berpengalaman membelajarkan sampai 15 tahun yang memiliki keinovatifan rendah sebesar 138,667. Sementara rerata kelompok dosen Jurusan PGSD FIP UNJ berpengalaman membelajarkan sampai 15 tahun yang memiliki keinovatifan tinggi sebesar 160. Apabila ditinjau dari aspek ide atau gagasan baru dalam pendidikan maka rerata kelompok dosen Jurusan PGSD FIP UNJ berpengalaman membelajarkan sampai 15 tahun yang memiliki keinovatifan rendah sebesar 46,75. Sementara rerata kelompok dosen Jurusan PGSD FIP UNJ berpengalaman membelajarkan sampai 15 tahun yang memiliki keinovatifan tinggi sebesar 56,25.

Apabila ditinjau dari aspek program baru dalam pendidikan maka rerata kelompok dosen Jurusan PGSD FIP UNJ berpengalaman membelajarkan sampai 15 tahun yang memiliki keinovatifan rendah sebesar 40. Sementara rerata kelompok dosen Jurusan PGSD FIP UNJ berpengalaman membelajarkan sampai 15 tahun yang memiliki keinovatifan tinggi sebesar 48,75. Apabila ditinjau dari aspek produk baru dalam pendidikan maka rerata kelompok dosen Jurusan PGSD FIP UNJ berpengalaman membelajarkan sampai 15 tahun yang memiliki keinovatifan rendah sebesar 45,25 . Sementara rerata kelompok dosen Jurusan PGSD FIP UNJ berpengalaman membelajarkan sampai 15 tahun yang memiliki keinovatifan tinggi sebesar 52,75.

Adapun rerata kelompok dosen Jurusan PGSD FIP UNJ berpengalaman membelajarkan lebih dari 15 tahun yang memiliki keinovatifan rendah sebesar 110,167. Sementara rerata kelompok dosen Jurusan PGSD FIP UNJ berpengalaman membelajarkan sampai 15 tahun yang memiliki keinovatifan tinggi sebesar 141,667. Apabila ditinjau dari aspek ide atau gagasan baru dalam pendidikan maka rerata kelompok dosen Jurusan PGSD FIP UNJ berpengalaman membelajarkan lebih dari 15 tahun yang memiliki keinovatifan rendah sebesar 36,5. Sementara rerata kelompok dosen Jurusan PGSD FIP UNJ berpengalaman membelajarkan sampai 15 tahun yang memiliki keinovatifan tinggi sebesar 52.

Apabila ditinjau dari aspek program baru dalam pendidikan maka rerata kelompok dosen Jurusan PGSD FIP UNJ berpengalaman membelajarkan lebih dari 15 tahun yang memiliki keinovatifan rendah sebesar 31,833. Sementara rerata kelompok dosen Jurusan PGSD FIP UNJ berpengalaman membelajarkan sampai 15 tahun yang memiliki keinovatifan tinggi sebesar 43,833. Apabila ditinjau dari aspek produk baru dalam pendidikan maka rerata kelompok dosen Jurusan PGSD FIP UNJ berpengalaman membelajarkan lebih dari 15 tahun yang memiliki keinovatifan rendah sebesar 33,333. Sementara rerata kelompok dosen Jurusan PGSD FIP UNJ berpengalaman membelajarkan sampai 15 tahun yang memiliki keinovatifan tinggi sebesar 49.

Berdasarkan hasil analisis data tersebut maka diperoleh rerata kelompok dosen Jurusan PGSD FIP UNJ yang memiliki pengalaman membelajarkan sampai 15 tahun lebih tinggi daripada kelompok dosen yang memiliki pengalaman membelajarkan lebih 
dari 15 tahun. Rendahnya rerata keinovatifan kelompok dosen yang memiliki pengalaman membelajarkan lebih dari 15 tahun dapat disebabkan karena latar belakang kelompok dosen tersebut yang berasal dari guru SPG dan SGO. Latar belakang ini memungkinkan kurang kondusifnya atmosfer akademik pada Jurusan PGSD. Pada sebagian dosen memungkinkan masih melekatnya budaya melaksanakan tugas membelajarkan semasa SPG atau SGO sehingga dapat mengakibatkan kurangnya motivasi untuk mengembangkan diri khususnya terkait tugas memberikan perkuliahan.

Selain itu, hal ini dapat pula disebabkan manajemen pengelolaan Jurusan PGSD yang kurang memberikan motivasi kepada dosen-dosen untuk secara terus menerus mengembangkan diri guna meningkatkan mutu perkuliahan. Manajemen pengelolaan Jurusan PGSD yang hanya berorientasi pada ketuntasan penyelesaian studi baik untuk mahasiswa reguler, alih program maupun kerja sama (Pemda Karawang Jawa Barat, Dikdas, Diklat maupun Hibah PHK PGSD A) tentunya akan mengakibatkan kurangnya mutu perkuliahan. Artinya, dengan banyaknya beban membelajarkan yang harus diampu dosen mengakibatkan kurangnya kesempatan untuk mengembangkan diri sehingga dosen kurang memiliki keinovatifan.

Faktor lain yang mungkin dapat mempengaruhi kurangnya keinovatifan dosen Jurusan PGSD FIP UNJ yang memiliki pengalaman membelajarkan lebih dari 15 tahun adalah faktor lokasi kampus. Kampus Jurusan PGSD FIP UNJ berlokasi di Jalan Setiabudi No. 1 Jakarta Selatan terpisah dari kampus induk, yakni di Jalan Rawamangun Muka Jakarta Timur. Kondisi ini dapat mempengaruhi kondisi akademik di Jurusan PGSD FIP UNJ karena tidak dipengaruhi oleh kondisi akademik jurusan atau prodi lainnya. Kondisi demikian mengakibatkan faktor eksternal jurusan kurang memberikan motivasi bagi dosendosen untuk memiliki sifat kompetisi dengan dosen jurusan atau prodi lainnya.

Sebagian besar dosen Jurusan PGSD FIP UNJ yang memiliki pengalaman membelajarkan lebih dari 15 tahun tidak mendapatkan tugas membelajarkan pada jurusan atau prodi lainnya. Kondisi ini mengakibatkan mereka tidak memiliki pengalaman membelajarkan selain di Jurusan PGSD. Kondisi ini tentunya kurang atau bahkan tidak memotivasi dosen untuk mengembangkan diri sehingga mereka kurang inovatif.

Sementara dosen yang memiliki pengalaman membelajarkan sampai 15 tahun sebagian besar mereka ditugaskan untuk mengampu mata kuliah di beberapa jurusan atau prodi lain. Kondisi ini memungkinkan dosen-dosen tersebut mendapatkan pengalaman lain selain memberikan perkuliahan pada Jurusan PGSD. Dosen-dosen tersebut tentunya mendapatkan pengalaman berdasarkan sosialisasi dengan dosen-dosen pada jurusan lainnya sehingga dapat memberikan motivasi untuk senantiasa mengembangkan diri. Hal ini berdampak pada lebihnya keinovatifan dibandingkan dengan dosen yang tidak memiliki pengalaman membelajarkan pada jurusan atau prodi lainnya.

\section{KESIMPULAN}

Berdasarkan hasil analisis maka penelitian ini menyimpulkan bahwa keinovatifan dosen Jurusan PGSD FIP UNJ yang berpengalaman membelajarkan sampai 15 tahun lebih tinggi daripada dosen yang berpengalaman membelajarkan lebih dari 15 tahun.

\section{DAFTAR PUSTAKA}

Drucker, P.F. (1985). Innovation and entrepreneurship. New York: Harper \& Collins.

Hender, E. S. \& George W. P. (1981). Change development in schools. London: McGraw-Hill Book Company.

O'Conner, C.A. (1993). The behavioral for organizational change: Strategy and skill for trainers and developers, the mcgraw-hill training series. London: McGraw-Hill Book Company.

Rogers, M. (1995). Diffusion of innovations. New York: The Free Press.

Scheirer, S, \& Marry, A. (1981). Program implementation: The organizational context. Beverly Hills London: Sage Publication.

Semiawan, C. (1986). Kurikulum pendidikan dasar 1994 dan kurikulum D-II PGSD. Jakarta: Depdikbud Dirjen Dikti.

Semiawan, C. (1994). Kurikulum pendidikan dasar 1994 dan kurikulum D-II PGSD. Jakarta: Depdikbud Dirjen Dikti.

Seymour, D.T. (1988). Developing academic program: The climate for innovation change. Washington DC: ASHE Association for the Study of Higher Education.

Tidd, J., Bessant, J. \& Pavitt, K. (1994). Managing innovation: Integrating technological, market and organizational change. New York: John Wiley \& Son. 
Undang-Undang Nomor 14 Tahun 2005 Tentang Guru dan Dosen. (2005). Jakarta: Depdiknas.

\section{KETERANGAN PENULIS}

Dra. Iva Sarifah, M.Pd., dilahirkan di Bandung, September 1965. Saat ini menjabat sebagai dosen
Pendidikan Guru Sekolah Dasar, Pendidikan Anak Usia Dini, dan Pendidikan Luar Biasa, FIP UNJ. Penulis pernah menulis buku yang berjudul Pedoman Matematika untuk Guru PLB yang diterbitkan pada tahun 2005. Penelitian terbaru yang dilakukan adalah Sikap Mahasiswa PGSD terhadap Profesi Keguruan, sebagai anggota pada tahun 2005. 